\title{
Simulasi Penjadwalan Teller PT Bank ABC Untuk Memangkas Waktu Tunggu Antrian Nasabah
}

\author{
Ella Levana Puspanegara ${ }^{1}$, Abraham Lomi ${ }^{2}$, Julianus Hutabarat ${ }^{3}$ \\ ${ }^{1}$ Mahasiswa Program Studi Teknik Industri S-2, Pascasarjana, ITN Malang \\ ${ }^{2}$ DosenTeknik Elektro, ITN Malang \\ ${ }^{3}$ Dosen Program Studi Teknik Industri S-2, Pascasarjana, ITN Malang
}

\begin{abstract}
Abstrak
Salah satu masalah yang sering muncul dalam industri perbankan ialah permasalahan mengenai waktu antrian.Antrian timbul ketika jumlah fasilitas pelayanan jasa lebih sedikit dibandingkan dengan jumlah orang yang memerlukan pelayanan.Dalam penelitian ini PT. Bank ABC mencoba untuk menjadwalkan sistem antrian dengan mengubah jumlah loket pelayanan. Teknik data dilakukan dengan metode observasi yaitu pengumpulan data dengan mengamati secara langsung terhadap objek penelitian dan diolah menggunakan software ARENA. Data yang didapatkan, CustomerNumber in sejumlah(860, 863 $872,875,869)$ dannumber out sejumlah(832, 818, 820, 834, 817). Flow time $(8.208,15.306,18.972$, $13.608,16.242)$ dan waiting time $(5.39,12.45,16.14,10.81,13.40)$. Number waiting dalam jumlah orang $(10,23,30,20,25)$.Didapatkan gambaran pemakaian waktu yang minimal dengan hasil yang cukup untuk setiap customer.Jumlah tellerefisien yang dibutuhkan pada sistem saat ini adalah cukup sebanyak 5 teller saja.
\end{abstract}

Kata Kunci : Layanan, waktu antrian, jumlah antrian, teller, bank

\section{Pendahuluan}

Perusahaan yang bergerak di bidang jasa layanan, seperti perbankan membutuhkan suatu manajemen operasional untuk membuat sistem yang lebih baik dari sistem telah dimiliki sebelumnya.Salah satu masalah yang sering muncul dalam industri perbankan ialah permasalahan mengenai antrian.Masalah antrian merupakan salah satu masalah yang sangat perlu diperhatikan.Kejadian antrian timbul ketika jumlah fasilitas pelayanan jasa lebih sedikit dibandingkan dengan jumlah orang yang memerlukan pelayanan bersangkutan [1].

Hal tersebut nampak dialami pada salah satu industri perbankan di Kota Malang.salah antrian muncul terlihat pada antrian teller pada suatu bank BUMN di wilayah Malang. Bank BUMN dimaksud ialah PT. Bank ABC.PT. Bank ABC melayani setoran, penarikan, pemindahan, serta pembayaran tagihan.Penumpukan pada antrian teller sering nampak terjadi, khususnya pada saat istirahat siang dan pada waktu-waktu tertentu.

Proses antrian sendiri dimulai saat pelanggan-pelanggan yang memerlukan pelayanan mulai datang dan mendapat nomer antrian. Proses antrian sendiri merupakan suatu proses yang berhubungan dengan kedatangan pelanggan pada suatu fasilitas pelayanan, menunggu dalam baris antrian jika belum dapat dilayani, dilayani dan akhirnya meninggalkan fasilitas tersebut sesudah dilayani [2].

Hal yang wajar jika setiap orang selalu mengharapkan untuk mendapatkan fasilitas pelayanan yang terbaik dengan waktu penungguan yang sebentar. Seringnya timbul antrian yang panjang akan mangakibatkan adanya ketidakpuasan bahkan hilangnya pelanggan. Dalam banyak hal, tambahan fasilitas pelayanan dapat diberikan untuk mengurangi antrian atau untuk mencegah timbulnya antrian.Permasalahnnya adalah apakah memadai secara ekonomis antara perbaikan sistem baru (seperti, penambahan pelayanan; memperbarui alat-alat; menerapkan sistem antrian baru dan sebagainya) dibandingkan dengan keadaan pada sistem sebelumnya. Biaya yang dikeluarkan karena pelayanan tambahan, akan menimbulkan pengurangan keuntungan sampai di bawah tingkat yang dapat diterima. 
Salah satu cara untuk memperbaiki fasilitas pelayanan dapat direncanakan dengan suatu metode. Sangat dimungkinkan dengan modifikasi sistem layanan.

PT. Bank ABC sendiri saat ini menerapkan sistem Multi Channel Multi Phase yang diaanggap dapat memenuhi optimalisasi layanan dengan mempunyai kelebihan seperti pelanggan dilayani pada beberapa loket dengan sistem first come first served sehingga dapat meminimalkan jumlah antrian dengan membuka banyak loket.

Dalam penelitian ini dicoba untuk menjadwalkan ulang sistem antrian dengan mengubah jumlah loket pelayanan. Hal lain yang dilakukan untuk meningkatkan efisiensi dan efektifitas layanan dengan mengurangi waktu pelayanan. Selain itu sistem perbankan yang semakin berkembang pesat dewasa ini mendorong dunia perbankan untuk terus berinovasi dengan mengoptimalkan kemajuan teknologi atau biasa disebut dengan Fintech (Financial Technology).Maraknya aplikasi online berbasis Fintech membuat dunia perbankan saat ini tidak hanya berfungsi sebagai tempat penyimpanan uang saja, tetapi lebih sebagai lembaga keuangan.Dimana bank juga dapat memeberikan solusi terhadap permasalah keuangan yang dimiliki oleh nasabahnya.

Penelitian ini juga akan menganalisa sistem antrian pada PT. Bank ABC yang menggunakan sistem antrian multi-channel dan multi-phase beserta hasil dan dampaknya dengan menggunakan data dari hasil pencatatan dalam beberapa waktu.

\section{Metode Penelitian}

Penelitian ini merupakan penelitian tindakan atau action researchdimana yang menjadi obyek penelitian yaitu antrian customerpada pelayanan teller PT. Bank ABC Cabang Malang dengan lama waktu penelitian 20 hari.

Populasi dalam penelitian ini adalah seluruh nasabah yang akan melakukan transaksi pada teller PT. Bank ABC Cabang Malang, atau bisa dikatakan tidak terbatas. Dalam menentukan sampel, teknik yang digunakan adalah teknik Purposive Sampling.Pengambilan sampel berdasarkan kriteriakriteria sebagai berikut.

a. Nasabah yang akan melakukan transaksi pada teller PT. Bank ABC Cabang Malang.

b. Penelitian dilakukan selama 20 hari (Oktober-Desember 2018)

c. Waktu yang diambil antara jam $08.00-16.00$ WIB

Data yang digunakan pada penelitian ini adalah data kuantitatif, yaitu data yang merupakan perhitungan statistik.Jumlah sampel yang diambil yaitu 40 kedatangan. Jumlah sampel ini telah memenuhi uji kecukupan data secara statistik, dengan hasil uji N'(jumlah pengamatan yang seharusnya dilakukan) adalah 37 data.Data yang diamati adalah waktu antar kedatangan dan durasi waktu pelayanan teller.Data-data tersebut akan melewati proses pengujian kecukupan data dan uji distribusi.

Dalam penelitian ini teknik data dilakukan dengan metode observasi yaitu pengumpulan data dengan mengamati secara langsung terhadap objek penelitian yang bersangkutan.Hasil observasi dapat dijadikan sebagai data pendukung untuk menganalisis dan mengambil keputusan. Pengolahan data dilakukan dengan menggunakan tool ARENA.

\section{Hasil Penelitian}

Analisis hasil simulasi dari proses simulasi pada sistem antrian PT. Bank ABC Cabang Basuki Rahmat Malang,didapatkan data dan hasil sebagai berikut:

1. Simulasi Transaksi Program dan Simulasi Transaksi Aktual

Tabel 1 : Data Simulasi Transaksi

\begin{tabular}{|c|c|c|}
\hline REPLIKASI & OUTPUT PROGRAM & OUTPUT AKTUAL \\
\hline 1 & 832 & 986 \\
\hline 2 & 818 & 839 \\
\hline 3 & 820 & 849 \\
\hline 4 & 834 & 802 \\
\hline 5 & 817 & 495 \\
\hline
\end{tabular}


Hasil simulasi pada Tabel 1 memperlihatkan pada replikasi 1, nasabah yang keluar dari sistem teller atau nasabah yang selesai dilayani oleh teller Bank ABC sebanyak 832 orang.Sedangkan kondisi aktual menunjukkan jumlah nasabah yang selesai dilayani oleh teller adalah sebanyak 986 orang. Apabila melihat output nasabah yang keluar sistem pada simulasi, dari replikasi 1 hingga 5, memiliki variasi nilai yang lebih rata dibandingkan dengan ouput nasabah aktual yang terjadi, dimana range output aktual berkisar antara 495-986 orang. Sedangkan output nasabah hasil simulasi berkisar antara 817-834 orang.

2. Hasil Pengolahan Data

Berikut merupakan tingkat utilitas resource pada sistem PT. Bank ABC Cabang Malang.

Tabel 2. Analisis Resource Utilization

\begin{tabular}{|c|c|c|c|c|c|}
\hline \multirow{2}{*}{$\begin{array}{c}\text { Resource } \\
\text { Utilization }\end{array}$} & \multicolumn{5}{|c|}{ Replikasi } \\
\cline { 2 - 6 } & 1 & 2 & 3 & 4 & 5 \\
\hline Teller 1 & 0.9993 & 0.9993 & 1.0000 & 0.9999 & 1.0000 \\
\hline Teller 2 & 0.9974 & 0.9988 & 0.9979 & 0.9990 & 0.9985 \\
\hline Teller 3 & 0.9953 & 0.9973 & 0.9980 & 0.9971 & 0.9966 \\
\hline Teller 4 & 0.9943 & 0.9955 & 0.9972 & 0.9963 & 0.9960 \\
\hline Teller 5 & 0.9956 & 0.9951 & 0.9954 & 0.9950 & 0.9953 \\
\hline
\end{tabular}

Tabel 2 memperlihatkan utilisasi 5 orang teller pada simulasi yang dijalankan dengan melakukan 5 replikasi. Nilai utilisasi seluruh teller berkisar antara nilai 0,9943-1. Nilai ini bisa dikatakan sangat tinggi, karena minimal 99,43\% jam kerja digunakan untuk melayani nasabah, dan 0,57\% saja bisa digunakan sebagai allowance seperti menghilangkan penat, atau kebutuhan akan kamar kecil (toilet).

3. Berdasarkan analisis hasil simulasi dari sistem antrian pada PT Bank ABC Cabang Malang yang telah dilakukan diatas, maka dapat disimpulkan bahwa dibutuhkan penambahan jumlah teller untuk efisiensiNumber In, Number Out, WIP (Work In Process), Flow Time, Waitting Time, Number Waitting dan Resource Utilization. Oleh karena itu, dibuatlah skenario perbaikan sistem adalah sebagai berikut :

Tabel 3. Rancangan dan Analisis Hasil Skenario

\begin{tabular}{|c|c|c|c|}
\hline Parameter & $\begin{array}{c}\text { Baseline } \\
(5 \text { teller })\end{array}$ & $\begin{array}{c}\text { Skenario 1 } \\
(\text { penambahan 1 teller) }\end{array}$ & $\begin{array}{c}\text { Skenario } 2 \\
(\text { penambahan } 2 \text { teller })\end{array}$ \\
\hline Numbber In & 860 orang & 866 orang & 863 orang \\
\hline Number Out & 832 orang & 861 orang & 859 orang \\
\hline Work In Process & 28 orang & 5 orang & 4 orang \\
\hline Flow Time & 8.208 menit & 2.988 menit & 2.874 menit \\
\hline Waitting Time & 5.390 menit & 0.102 menit & 0.006 menit \\
\hline Number Waitting & $9.7403 \approx 10$ orang & $0.1934 \approx 1$ orang & $0.0149 \approx 1$ orang \\
\hline
\end{tabular}

Tabel 3 menunjukkan hasil rancangan simulasi, menggunakan 5 teller seperti kondisi aktual (baseline), dan penambahan hingga 2 teller (skenario 1 dan 2). Dari tabel tersebut dapat dilihat semakin besar jumlah teller, maka akan memperkecil work in process, flow time, waiting time, dan number of waiting, dengan kata lain jumlah teller berbanding terbalik dengan parameter. Oleh karena itu akan berimbas pada number in dan out yang lebih besar. Kondisi ini tentunya akan membuat antrian ,udah terurai, dan memperkecil utilitas dari masing-masing teller. Besarnya utilitas akan berbanding terbalik dengan jumla teller yang bekerja. Kondisi ini ditunjukkan oleh Tabel 4 (dalam angka) dan Gambar 1 (dalam grafik), dimana baseline memiliki performa utilitas rata-rata 0,9964 , berubah menjadi 0,8639 dengan penambahan 1 teller dan 0,7354 dengan penambahan 2 teller 
Tabel 4. Rancangan dan Analisis Hasil Skenario Masing-masing Teller

\begin{tabular}{|c|c|c|c|}
\hline Parameter & $\begin{array}{c}\text { Baseline } \\
\text { (5 teller) }\end{array}$ & $\begin{array}{c}\text { Skenario 1 } \\
\text { (penambahan 1 teller) }\end{array}$ & $\begin{array}{c}\text { Skenario 2 } \\
\text { (penambahan 2 teller) }\end{array}$ \\
\hline Resource Utilization & & & \\
\hline Teller 1 & 0.9993 & 0.9353 & 0.9155 \\
\hline Teller 2 & 0.9974 & 0.9113 & 0.8848 \\
\hline Teller 3 & 0.9953 & 0.9153 & 0.8318 \\
\hline Teller 4 & 0.9943 & 0.8750 & 0.8031 \\
\hline Teller 5 & 0.9956 & 0.8173 & 0.7326 \\
\hline Teller 6 & - & 0.7297 & 0.6052 \\
\hline Teller 7 & - & - & 0.3754 \\
\hline Rata-Rata Utilitas & 0.9964 & 0.8639 & 0.7354 \\
\hline
\end{tabular}

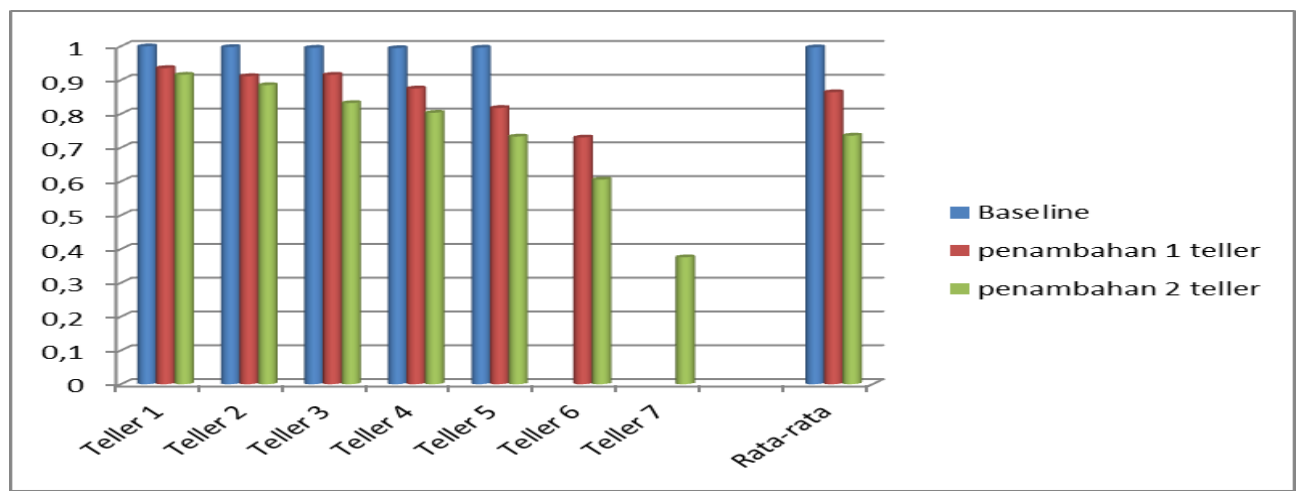

Gambar 1. Analisis Kinerja Masing-masing Teller

\section{Pembahasan}

Proses simulasi pada objek penelitian sebagai berikut:

1. Jumlah teller eksistimg pada PT Bank ABCCabang Malang sejumlah 5 orang dengan jumlah transaksi rata-rata selama 3 bulan sebanyak 860 transaksi.

2. Number In

Number in menunjukkan jumlah entitas yang masuk atau akan diproses dalam sebuah sistem. Banyaknya customer yang masuk ke dalam sistem pada PT Bank ABC Cabang Malang dari hasil simulasi yaitu sebanyak 860 customers.Jika melihat dari segi keefektifan dengan adanya teller sebanyak 5 orang tentu ini sangat kurang untuk pelayanan maksimal dari penyedia jasa ke pengguna jasa. Disini terdapat hubungan kesimbangan antara pelanggan secara adil dan kinerja sistem menjadi tidak terpenuhi seperti penelitian yang pernah dilakukan oleh Al-Jumaily dkk [3].

3. Number Out

Number out menunjukkan jumlah entitas yang keluar atau selesai diproses dari sistem.Banyaknya customer yang keluar dari sistem pada PT Bank ABC Cabang Malang dari hasil simulasi yaitu sebanyak 832 customers.Pada pelanggan yang keluar (number out) didapatkan suatu angka yang tidak sama dengan pelanggan atau custoner yang masuk (number in). Hal ini bisa mengindikasikan beberapa hal seperti adanya progress yang negatif seperti ketidakpuasan pelanggan akibat kekecewaan terhadap layanan atau mungkin keterbatasan waktu dari customer itu sendiri. Ada beberapa hal yang menjadi perhitungan yang mempengaruhi keseimbangan number in dan number out ini salah satunya manajemen sistem antrian seperti yang disampaikan pada suatu penelitian. Manfaat yang dapat berdampak secara langsung dan tidak langsung pada sistem antrian, seperti :

- Dapat memprediksi dan meramalkan jumlah pelanggan

- Mempekirakan jumlah optimal pekerja

- Menilai konsistensi pelayanan pekerja

- Meningkatkan produktivitas dan semangat pekerja, dikarenakan pelayanan berjalan secara sistematis dan efisien

- Memberikan keleluasaan berinteraksi dengan pelanggan 
- Meningkatkan kenyamanan dalam pelayanan, dikarenakan pelanggan diperlakukan sama dan secara efisien. Membuat laporan secara statistik yang dapat dipergunakan dalam proses penggambilan keputusan jajaran manajemen inti[4].

\section{Flow Time}

Flow time adalah total waktu yang dibutuhkan keseluruhan proses dalam simulasi. Lamanya total waktu yang dibutuhkan customer dalam sistem yaitu selama 0.025 jam atau sama dengan 1.5 menit setiap customer.Total waktu dalam menanganai setiap cutomer berbeda-beda. Namun pada penelitian ini didapatkan flow time yang relatif baik dimana dalam menangani setiap customer relatif cepat. Kemudian dapat dilihat juga dari tidak jauhnya bebrbeda antara number in dan number out yang didapatkan. Penanganan yang lama atau flow time yang panjang dapat mengakibatkan ketidakpuasan pelanggan [5] dimana didapatkan kesimpulan adanya garis panjang dalam layanan teller bank tradisional sehingga didaptkan hasil yang bertolak belakang dari penelitian ini.

5. Resource Utilization

Resource utilization merupakan tingkat kontribusi sebuah resource, baik itu operator ataupun mesin dalam suatu sistem. Berikut merupakan tingkat utilitas resource pada sistem PT. Bank ABC Cabang Basuki Rahmat, Malang. Untuk tingkat utilitas resource pada sistem berkisar antara 0\% hingga $88.23 \%$ dan untuk tingkat utilitas tertinggi adalah teller 1 dengan nilai $88.23 \%$ karena dalam sistem ini menggunakan rules smallest number busy. Sehingga dari hasil tersebut maka dapat disimpulkan bahwa jumlah tellerefisien yang dibutuhkan pada sistem PT. Bank ABC Cabang Malang dengan sistem yang berlaku saat ini adalah sebanyak 5 teller saja.

\section{Kesimpulan}

Pada penelitian ini kesimpulan yang dapat diambil antara lain:

1. Lamanya total waktu yang dibutuhkan customer dalam sistem yaitu selama 0.025 jam atau sama dengan 1.5 menit setiap customer sehingga menggambarkan pemakaian waktu yang minimal dengan hasil yang cukup untuk setiap customer .

2. Untuk tingkat utilitas resource pada sistem berkisar antara $0 \%$ hingga $88.23 \%$ dan untuk tingkat utilitas tertinggi adalah teller 1 dengan nilai $88.23 \%$ karena dalam sistem ini menggunakan rules smallest number busy. Sehingga dari hasil tersebut maka dapat disimpulkan bahwa jumlah tellerefisien yang dibutuhkan pada sistem PT Bank ABC Malang dengan sistem yang berlaku saat ini adalah cukup sebanyak 5 teller saja.

3. Dari simulasi kondisi aktual, yaitu baseline, menunjukkan utilitas yang sangat tinggi untuk masingmasing teller, yang berkisar antara 99,43\%-100\%. Tingginya utilitas teller ini dapat dikurangi dengan memanfaatkan teknologi yang dimiliki PT Bank ABC, yang diharapkan dapat membantu pelayanan dan mempercepat penguraian antrian dengan teknologi seperti ATM yang ada di berbagai tempat dan teknologi Fintech, sehingga PT Bank ABC Cabang Malang dapat memenuhi keinginan dan kepuasan dari pelanggan atau customer.

\section{Daftar Referensi}

[1] Taha, Hamdy A. (1996). Riset Operasi Jilid 2 (halaman 189-208). Binarupa Aksara. Jakarta.

[2] Kakiay, Thomas J. (2004). Dasar Teori Antrian Untuk Kehidupan Nyata (halaman 4-6, 17-18). Penerbit Andi. Yogyakarta.

[3] Al-Jumaily ASA, Al-Jobori HKT. (2011). Automatic Queuing Model for Banking Applications. (IJACSA) International Journal of Advanced Computer Science and Applications, Vol. 2, No. 7. Bahrain.

[4] Ahmed.SZ et al. (2016). Automated Queue Management System. Global Journal of Management and Business Research. Bangladesh.

[5] Machline C, Serson FM. (2014). A study of queues and customer service in retail bank Agencies. Brazil.POMS International Conferrence 2014, Singapore. 